\title{
DIASPORA ENTREPRENEURS' PUSH AND PULL INSTITUTIONAL FACTORS FOR INVESTING IN AFRICA: INSIGHTS FROM AFRICAN RETURNEES FROM THE UNITED KINGDOM
}

\section{Dr. Frank Nyame-Asiamah}

Leicester Castle Business School

De Montfort University

The Gateway, Leicester, LE1 9BH

frank.nyame-asiamah@dmu.ac.uk

00441163664280

Dr. Isaac Oduro Amoako

Liverpool Business School

Liverpool John Moores University, Liverpool, UK

E-mail: I.O.Amoako@limu.ac.uk

\author{
Dr. Joseph Amankwah-Amoah* \\ Kent Business School \\ University of Kent, Kent ME4 4TE \\ TEL: +44 (0) 1634 (88)8870 \\ E-mail: J.Amankwah-Amoah@kent.ac.uk
}

\author{
Prof. Yaw A. Debrah \\ Swansea University \\ School of Management \\ Singleton Park, Swansea, SA2 8PP \\ E-mail: y.a.debrah@swansea.ac.uk
}

*Corresponding author 


\begin{abstract}
Applying the institution-based views, this article conceptualises how diaspora entrepreneurs take stimuli from the push and pull institutional factors to develop business enterprises in their countries of origin. Using cases of African diaspora entrepreneurs in the UK and the grounded theory methodological approach, our conceptualised model demonstrates that the diasporas use the new knowledge, skills and wealth they have gained in the UK in tandem with support from trusted family, kinship and business ties at home to develop enterprises. It further demonstrates that diaspora entrepreneurs foster resilience to withstand weak formal institutions in their countries of origin and the discriminatory obstacles in the UK. We also found that institutional barriers which served as push factors that encouraged or forced migrants to leave their home countries to seek greener pastures abroad may later become pull factors that enable them to engage in diaspora entrepreneurship which is often characterised by paradoxes. Particularly, the informal institutions that constrain foreign investors can become assets for African diaspora entrepreneurs and help them set up new businesses and exploit market opportunities in Africa. The implications of the study for diaspora entrepreneurship literature are outlined.
\end{abstract}

Keywords: Africa; institutional challenges; policy; diaspora entrepreneurs; entrepreneurship; institutions. 


\section{Introduction}

A great deal of research in entrepreneurship has demonstrated that immigrant and diaspora entrepreneurs contribute substantially not only to their countries of origin's small and medium enterprises (SMEs) development but also their host countries' economies (Chand, 2016; Chrysostome, 2014; Newland and Tanaka, 2010; Riddle and Brinkerhoff, 2011; Stoyanov, Woodward and Stoyanova, 2018b). In particular, diaspora entrepreneurs contribute to job creation, foreign currency inflows and economic growth in their countries of origin (Brinkerhoff, 2016; Coniglio and Brzozowski, 2016; Riddle and Brinkerhoff, 2011; Riddle, Hrivnak and Nielsen, 2010; Mani 2004) and develop self-employed businesses, SMEs and niche market products in their countries of residence (Crick and Chaudhry, 2013; Jones, Ram, Edwards, Kiselinchev and Muchenje, 2014; Smallbone, Bertotti and Ekanem, 2005).

These forms of diaspora entrepreneurs' activities are seen in emerging economies and some African countries where socio-political stability, economic prosperity and talent promotion programmes serve as attractors that pull diaspora experts and migrant returnees to invest in their countries of origin (Logan, 2009; Lu and Zhang, 2015; Zweig, 2006). More markedly, previous research indicates that diaspora entrepreneurs' SME development in their countries of origin is enhanced by their relative understanding of local institutional environment which includes access to informal networks and culture which may be oblivious to their foreign counterparts who may wish to invest in such local markets (Brinkerhoff, 2016; Nielsen and Riddle, 2010; Rana and Elo, 2017; Riddle and Brinkerhoff, 2011). Successful diaspora entrepreneurs often acknowledge that their host countries' strong institutional structures such as effective enterprise education, business advice services and the rule of law are some of the enabling factors that encourage them to develop and sustain their enterprises (Riddle and Brinkerhoff, 2011; Smallbone et al., 2005). 
However, the diaspora entrepreneurs' choice to invest or start new ventures in their countries of origin or residence does not always depend on their abilities to explore and exploit favourable institutional factors as they persistently have to navigate some institutional constraints before making progress (Jones, et al. 2014; Rana and Elo, 2017; Smallbone et al., 2005). For instance, weak formal institutions such as unenforced enterprise regulations and corruption limit African diaspora entrepreneurs' ability to develop, expand and sustain their SMEs in Africa (Bratton, 2007; Chrysostome, 2014).

In the countries of residence, migrants face constrained career advancement, receive low wages, and are subjected to discrimination due to their 'ethnically homogeneous social networks' (Jones et al., 2014; Kloosterman, Russinovich and Yeboah, 2016) and restrictive policies towards migrant workers (Sepulveda, Syrett and Lyon, 2011; Syrett and Sepulveda, 2012). Some authors make specific observations that Asian owned firms in London's creative industry face competition and stereotypes in the UK's mainstream music and performing arts market (Smallbone et al., 2005). These lead us to argue that the challenges confronting migrants and the opportunities available to them present institutional paradoxes of diaspora entrepreneurship (see Dodd and Anderson, 2001), a situation where the enabling institutional environments pose unfavourable conditions for entrepreneurs to develop their enterprises. However, research has yet to theorise how diaspora entrepreneurs can simultaneously: (i) take stimuli from the challenges and prospects of domiciling abroad to exploit business opportunities in their countries of origin and (ii) take motivation from informal network and cultivate resilience in weak institutional environments, to explore and develop business ventures in their native countries.

Many attempts to conceptualise factors affecting diaspora entrepreneurs' motivation for investing in their countries of origin have hitherto not combined the paradoxical pull and push institutional factors in both 'home' and residence countries, to explain diaspora entrepreneurship and SME 
development in emerging economies, such as African countries (Jones et al., 2014; Nielsen and Riddle, 2010; Riddle and Brinkerhoff, 2011). Nielsen and Riddle (2010), for instance, report that diaspora entrepreneurs' motives are based on their decisions to contribute to their native countries' economies, their economic support for friends and families and the desire to enhance their social standings in their diaspora communities or countries of origin. However, theorising the combined pull and push institutional factors of diaspora entrepreneurs' countries of origin and residence that influence the migrants to invest in their native countries was seemingly not the focus of their study. This article therefore aims to conceptualise how institutional factors in African diaspora entrepreneurs' countries of origin, as well as in their countries of residence, motivate them to explore and exploit business opportunities in their countries of origin.

Researchers who adopt the mixed embeddedness theory to explain the relationship between less resourced diaspora entrepreneurs and their unwelcoming business environment (Jones et al., 2014) have not gone far to address the institutional ironies of immigrant entrepreneurs' motivation for doing business in emerging economies. Studies that use the theory to challenge the discrimination effects on diaspora entrepreneurs and their business activities have not done so either (Kloosterman, 2010; Kloosterman, Rusinovic and Yeboah, 2016). Jones et al (2014) applied mixed embeddedness perspectives to understand the experiences of 165 migrant business owners including African migrants in the East Midlands area of the UK and found that the migrants operate in low-value business ventures, as racism continues to affect their business activities and structural constraints limit the scope of their enterprises in the UK. Jones et al.'s (2014) eloquent contribution insinuates that the challenging institutional environment and labour market discrimination confront migrants and shape their entrepreneurial trajectories, yet they do not emphasise how the institutional challenges might influence the UK immigrant entrepreneurs to direct their business attention to different institutional contexts such as their countries of origin. 
Although others have broadly explored institutions and diaspora entrepreneurship in the migrants' countries of origin, these do not relate directly to the challenging institutional environment of the host countries (Rana and Elo, 2017; Riddle and Brinkerhoff, 2011). Using a case study of Thamel.com in Nepal, Riddle and Brinkerhoff(2011) applied institutions and acculturation models to demonstrate that diaspora entrepreneurs' acceptance of new institutional roles and practices of a new cultural setting, influence them to change institutional arrangements, beliefs, norms and operations of business ventures in their countries of origin. Though the Thamel.com story is influential, it revolves around the case of Bal Joshi, a Nepal-born successful entrepreneur in the USA, who has stimulated institutional change in his country of origin by generating new beliefs, cultures and business practices he has acculturated from the USA. We argue that the insights from Riddle and Brinkerhoff (2011) together with Nielsen and Riddle's (2010) and Jones et al.'s (2014) evade our theoretical understanding of the way African diaspora entrepreneurs navigate the institutional challenges of their countries of residence and institutional weaknesses of their countries of origin, and how these help resolve the institutional paradoxes of diaspora entrepreneurship.

To address these theoretical omissions, Su, Zhai and Karlsson (2017) encourage researchers to explore other institutional forms such as the role of family, home country institutional factors, the institutional distance between home country and host country, and the way these impact on entrepreneurship development in different contexts. This advice is a perfect fit for the African entrepreneurship context where there are prominent grounds to combine formal and informal institutions (Amoako 2018; Peng, Sun, Pinkham and Chen, 2009) and develop new theoretical insights to fill the paucity of diaspora entrepreneurship research in sub-Saharan Africa (Chrysostome, 2014). The returning question is: How can we theorise diaspora entrepreneurs' institutional environments that serve as pull and push factors in the African diaspora entrepreneurs' countries of residence and origin and to motivate them to invest in their countries of origin? 
In an attempt to address the research question, we conceptualise how pull and push institutional factors in African diaspora entrepreneurs' countries of origin as well as in their countries of residence motivate them to explore and exploit business opportunities in their countries of origin. We do this by drawing on institution-based views (Brinkerhoff, 2016; Bruton, Ahlstrom and Li, 2010; Hardy et al., 2014; Parker, 2010; Rana and Elo, 2017; Riddle and Brinkerhoff, 2011; Peng, Wang and Jiang, 2008; Peng et al., 2009; Sepulveda et al., 2011; Syrett and Sepulveda, 2012; Zoogah, Peng and Woldu, 2015; Zhu, Wittmann \& Peng, 2012) to examine how formal institutions and the embedded networks of immigrant entrepreneurs and their business ventures (Crick and Chaudhry, 2013; Munkejord, 2015; Stoyanov et al., 2018a) can inform the way we resolve the institutional paradoxes in African diaspora entrepreneurship. Though existing studies have used different institutional contexts to frame diaspora entrepreneurship, we take the view that no single theory can effectively account for the motive of internationalising diaspora entrepreneurship (Crick and Chaudhry, 2013; Riddle and Brinkerhoff, 2011).

The remainder of the paper is organised as follows: First, we present a review of the literature on institutions and diaspora entrepreneurship. We then narrow the debate to Africa diaspora context to consolidate the propositions for the study. Second, we set out the research context and data collection methods and explain the approaches to data analysis. Third, we interpret the findings in two phases to develop insights for theory building. Four, we discuss our findings and then move on to the concluding section to outline contributions to theory, practice and policy, and offer suggestions for future research. 


\section{Institutions and diaspora entrepreneurship in emerging economies}

Much research on entrepreneurship has drawn from economic (North, 1990) and sociological (Scott, 2001) perspectives on institutions to explain how resource allocations, formal structures and socio-cultural norms interact to shape enterprise formation and development in different contexts (see Amankwah-Amoah, 2016; Amoako, Akwei and Damoah, 2018; Brinkerhoff, 2016; Bruton, Ahlstrom and Li, 2010; Hardy et al, 2014; Parker, 2010; Peng et al, 2008; Peng et al., 2009; Zoogah et al., 2015). Diaspora entrepreneurship scholars have also followed suit to appropriate economic and social dimensions of institutions to understand migrant entrepreneurs' institutional challenges and prospects in their countries of residence (Riddle and Brinkerhoff, 2011; Sepulveda et al., 2011; Syrett and Sepulveda, 2012) and countries of origin (see Brinkerhoff, 2016; Coniglio and Brzozowski, 2016; Nkongolo-Bakenda and Chrysostome, 2013; Ojo, Nwankwo and Gbadamosi, 2013) and how these implicate on their business resources and their successes or failures. We discuss these as follows:

\section{Institutions}

Institutions are loosely described to cover elements of governments, tax and legal systems, democracy, conventions, ideologies, education, science, families, religions, ethics and similar social and economic structures that impact on actors and their socio-economic ventures (Bruton, Ahlstrom and Li, 2010; Hardy et al, 2014; Parker, 2010; Peng et al., 2009; Zoogah et al., 2015). Scott (2001) has categorised institutions into three supportive pillars of regulative, normative and cognitive dimensions of sociology: The regulative pillar explains the coercive power of governments to force individuals to act in specified ways or to induce some action (Peng, 2014); the cognitive pillar describes internalised values and assumptions that guide individuals' thoughts and interpretations; and the normative pillar summarises the value principles and actions of individuals into collective norms, to regulate behaviour (Peng et al., 2009). The sociological 
dimensions invoke laws, regulations, norms, cultural values and ethics to influence enterprise ideas and development (Peng, 2014; Scott, 2001).

The economics view of institution (North, 1990) is categorised into formal and informal institutions. Formal institutions comprise the constitutional and the legal frameworks that provide the "rules of the game" and promote wealth-generating entrepreneurial activity for economic growth (North, 1990; Sobel, 2008). As officially regulated structures of a country, formal institutions are determined and maintained by governments to help legitimise economic and political stability for entrepreneurial development (Spencer, Murtha and Lenway, 2005). This is to ensure that state-backed institutions such as the judiciary and courts are authoritatively organised to enforce contractual relationships and financial compliance while business-support agencies are empowered to bring effective administrative support to entrepreneurial activities at reasonable costs (Amoako, 2018; Sobel, 2008; Welter and Smallbone, 2011).

Analysis of science and human capital development policies in Portugal between 1970-2010 shows that state-backed institutional programmes such as recognised research capacity building can promote 'brain gain' and 'brain circulation' of $\mathrm{PhD}$ holders (Heitor, Horta and Mendonça, 2014). Similarly, the positive evolution of the Chinese economy with high annual growth rates and open market policies has encouraged the recruitment of foreign-trained scientists in competitive enterprises and promoted return migration of tens of thousands of citizens who studied abroad to support Chinese enterprise development (Lu and Zhang, 2015; Zweig, 2006).

Informal institutions include implicit rules such as social conventions, cultural norms, codes of ethics and personal networks (North, 2012). Informal institutions emphasise shared social values, attitudes and behaviours that shape economic relationships (Peng et al, 2009) and impact on individual's decision to engage in entrepreneurship and pre-contract arrangements (Sobel, 2008). Though the economic and sociological categorisation of institutions may differ, entrepreneurship 
and strategy researchers have informed us that the two institutional forms are explained interchangeably when applying their meanings to business decisions and resource allocations (Hardy et al, 2014; Parker, 2010; Rana and Elo, 2017; Riddle and Brinkerhoff, 2011; Zhu et al., 2012; Zoogah et al., 2015).

Peng et al (2009, p. 64), for example, have devised a valuable integrative framework to align institutional dimensions from both economics and sociology, and other associated subjects, to show that formal institutions exemplify laws, regulations and rules, to correspond with the regulative pillar's coerciveness. They cite norm, culture and ethics as examples that bring informal institutions to match cognitive and normative pillars. We argue that the alignment of institutional dimensions enriches our understanding of the way institutions are interpreted, applied and shared in different entrepreneurial contexts, to create paradoxical prospects and constraints for diaspora entrepreneurship and motivate migrant entrepreneurs' decisions to invest in their native countries (Rana and Elo, 2017; Riddle and Brinkerhoff, 2011; Sepulveda et al., 2011; Syrett and Sepulveda, 2012; Zoogah et al., 2015).

\section{Challenges and prospects}

Past studies have demonstrated that weaknesses in formal institutions create barriers to business growth (Amankwah-Amoah, and Hinson, 2019; Amankwah-Amoah, Chen, Wang, Khan, and Chen, 2019; Zhu et al., 2012). Weak formal institutions may even serve as a recipe for corrupt practices that allow unscrupulous entrepreneurial engagements to persist in business transactions in Africa (Amoako and Lyon, 2014; Bratton, 2007), countries of the former Soviet bloc (Tonoyan, Strohmeyer, Habib and Perlitz, 2010) and other developing countries such as India (Das and Das, 2014). It has been suggested that corruption in formal institutions reduces confidence in entrepreneurial development (Tonoyan et al., 2010). Corruption may stem from deficient legal frameworks where entrepreneurs perceive courts and police as incompetent of resolving business disagreements adequately and protecting property rights robustly (Tonoyan et al., 2010). One of 
the outcomes of this is that foreign investors may be deterred by weak formal institutions and bribery scandals (Chrysostome, 2014).

Institutional weaknesses in emerging markets are often seen as push factors that encourage people or force migrants to leave their home countries to seek opportunities in distant lands (Hardy et al., 2014; Massey, 1998). In Riddle et al.'s (2010) view, institutional challenges include low-quality educational programmes, lack of information about products, insufficient local credit markets, lack of third-party certification, and poor transaction support institutions. The diaspora and returnee migrants who want to invest in their countries of origin may still face constraints such as corruption and mistrust, vague tax regimes and administrative red tape, which can curtail their willingness to invest in the developing world (Chrysostome, 2014) or have difficulty in re-integrating into their countries of origin's job market. However, existing studies have indicated that indigenous and diaspora entrepreneurs may employ informal networks and use their local knowledge of norms and traditional cultures to operate successful business in institutionally constrained environments (Ndhlovu and Ndinda, 2017; Peng et al., 2008; Rana and Elo, 2017; Zhu et al., 2012).

Migrants are not only pushed out by weak institutions, they are also attracted by the opportunities at their countries of origin (Diamantides, 1992). Syrett and Sepulveda (2012, p.243) has outlined 'flexible labour markets', 'globally competitive enterprise activity', 'the appeal of living and working in a diverse multicultural city' and 'entrepreneurial activity, innovation and creativity' as some of the pull factors that attract migrants to their destinations. Research indicates that diaspora entrepreneurs gain international knowledge and expertise that enable them to identify opportunities and pursue internationalisation and form new business ventures (Nkongolo-Bakenda and Chrysostome, 2013; Rana and Elo, 2017; Riddle and Brinkerhoff, 2011).

Countries of residence are not always a constraint-free institutional environment for migrants who are often confronted with racial discrimination, unemployment, low wages, constrained career 
advancement and poverty (Jones et al., 2014; Kloosterman, 2010; Kloosterman et al., 2016; Smallbone et al., 2005; Teixeira and Truelove, 2007). To turn the challenges of the job market into inspirations, some diaspora entrepreneurs set up small-scale businesses and develop them in their countries of origin (Dana, 2007; Kloosterman, Van Der Leun and Rath, 1999) or take selfemployment as their best option to get round discriminatory obstacles with subsequent implications for their home countries' economic development (World Migration Report, 2015).

By circumventing the discriminatory practices and labour market constraints in their countries of residence (Basu 1998; Bruder and Räthke-Döppner, 2008; Naudé, Siegel and Marchand, 2017), diaspora entrepreneurs from developing countries often use informal institutions and social networks to engage in entrepreneurship and contribute to their countries of origin's economic development (Nielsen and Riddle, 2007; Rana and Elo, 2017). Indeed, the support from family and ethnic ties can encourage them to establish transnational enterprises (Bhat and Narayan, 2010; Cheung, 2004). A number of scholars have observed that diaspora entrepreneurs' motives for investing might be based on their sense of obligation and desire to contribute to their native countries' economies, support for friends and families, and enhancing their social standing in diaspora communities (Aharoni, 1966; Gillespie, Riddle, Sayre and Sturges, 1999; Nielsen and Riddle, 2010).

\section{Institutions, resources and agency}

Although the network of resources embedded in the homogenous ties of migrants can lessen some institutional challenges that confront migrants' access to resources such as capital in their countries of residence (Munkejord, 2015; Stoyanov et al., 2018a), some authors are unenthusiastic about diaspora entrepreneurs' limited access to resources due in part to "restrictive and selective policies towards migrant workers" (Syrett and Sepulveda, 2012, p.242) which often lead to the “entrepreneurs feeling excluded and discriminated against" (Sepulveda, Syrett and Lyon, 2011, 
p.489). In the countries of origin, which often fall within the emerging economies category, a resource-based view acknowledges that entrepreneurs and SMEs tend to lack financial resources because of the weak institutional environments and negative attitudes they receive from banks for not backing their investments with securities (Adomako et al., 2019; Zoogah et al., 2015).

The far-fetching consequences of limited entrepreneurial resources such as telecommunication, roads and energy supplies are constrained business developments (Cavusgil, Ghauri and Agarwal, 2002; Tracey and Phillips, 2011) and limited product experimentation and innovations (De Carolis, Yang, Deeds and Nelling, 2009). Regardless of the benefits of using resource and institutional capabilities to support enterprise development (Parker, 2010), the combined omission of these capabilities can restrict new business development, especially in emerging markets where the economic environment is weak (Peng et al., 2009; Zoogah et al., 2015). For example, a limited access to funding and enterprise support infrastructure such as legal aid and fairer taxes could create barriers for potential entrepreneurs and their ability to start-up new businesses, make profits, innovate and grow (Zoogah et al., 2015).

However, past studies have indicated that resource constraints and institutional barriers can drive creativity and innovation (Hoegl, Gibbert and Mazursky, 2008; van Burg, Podoynitsyna, Beck and Lommelen, 2011). Amankwah-Amoah, Debrah and Nuertey (2018) suggested that institutional constraints such as lack of access to finance and weak legal enforcement mechanisms can compel firms to experiment and innovate, as entrepreneurs can adopt new or inventive business models. Fewer resources in competitive industries, for example, are not a liability for some new ventures operating in such environments but rather an opportunity that compels them to innovate (Katila and Shane, 2005). The discourse here validates the claim that "the enterprise culture model is riddled with paradox" (Dodd and Anderson, 2001, p. 23). 
Therefore, the recognition that institutions determine the availability of resources for enterprise development could only be part of the story because entrepreneurial agency, acting as agents of change have the agility to reconfigure their institutional space, do things differently and develop their enterprises (Abrutyn and Van Ness, 2015; Bendickson, Muldoon, Liguori and Davis, 2016: Garud, Hardy and Maguire, 2007). Specifically in the immigrant entrepreneurship context, Villares-Varela, Ram and Jones (2018, p.957) make the point that "migrant entrepreneurs are shown to be highly active social agents, displaying considerable inventiveness in their deployment of a multitude of survival strategies in the face of disadvantage". Entrepreneurs can access resources such as support and motivation, expert opinion and advice, opportunities and information through networks (Manning et al., 1989; Parker, 2010; Stoyanov et al., 2018a) and also through utilising their own savings or personal wealth (Amoako, 2018; Beck, DermirgucKunt and Maksimovic, 2005) to overcome bureaucratic institutional barriers.

The challenge for diaspora entrepreneurs is that family members whom the entrepreneurs engage to look after their business often compromise the traditional owner-employee relationships in agency theory and place emphasis on their own self-interest to jeopardise the performance of their care-taker enterprises (see Bendickson et al., 2016). It thus explains a lack of socially embedded context of family ties in agency theory (Bendickson et al., 2016). However, diaspora entrepreneurship researchers have recognised migrants as change agents in their native countries, drawing on agency perspective to illustrate that individuals have the "ability to shape institutions to achieve their goals" (Riddle and Brinkerhoff, 2011, p.673). 


\section{Research methodology}

\section{African Diaspora context}

The term 'African diaspora' has historical roots in the adventurous colonial era of slavery but in contemporary migration discourse it denotes people who migrate from Africa to live, work and settle outside the African continent (Palmer, 2000; Zeleza, 2005). The United Nations (2017) puts the surging numbers of people migrating from Africa to other countries to an estimated 36.3 million, representing $14.1 \%$ of the world's migration. The contemporary migration of Africans is caused by forced actions or voluntary decisions. Research suggests that natural disasters, armed conflicts, human rights abuses, political persecution and other harsh socio-economic reasons force people to flee from Africa and to seek safe havens in their destination countries (Jones et al., 2014). In contrast, some migrants leave Africa in search for education, employment and better economic opportunities (Mohan and Zack-Williams, 2002). These are professionals, traders, students and many others whose economic mobility has arguably been engendered by economic, political and social crises in many African countries (Zeleza, 2005).

However, the contemporary migrants of African descents have better socio-cultural interconnectedness with their native countries because of globalisation and technological advancement, which allow migrants to retain their economic, psychological, social and family ties (Mohan and Zack-Williams, 2002; Zeleza, 2005; see also You et al., 2019). Migration, which was until recently viewed as 'brain drain' (see Cuhls, 2007) and causing human capital loss to African countries, is now seen as 'brain circulation' or 'brain gain', creating opportunities for knowledge transfer, improved human resource development and social capital enhancement for the migrants' native countries, with implications for enterprise development (Brinkerhoff, 2016; Radwan and Sakr, 2018; Tung, 2008). 
Logan (2009) captions the 'brain gain' effect as 'Reverse and Return Transfer of Technology' that enables the African home countries to benefit from the embedded skills of the returning diaspora emigrants who are able to contribute towards national development efforts and economic progress while Radwan and Sakr (2018) move a step further to argue that brain circulation can improve EU-Africa cooperation and mitigate brain drain. The financial benefits from brain gain is seen in the regular African diaspora's remittances that represent a huge source of income for families and the economies of many developing economies. For instance, the flow of remittances to sub Saharan African countries stood at $\$ 33$ billion in 2016 and this was projected to increase to $\$ 34.1$ billion in 2017 and \$35.7 billion in 2018 (The World Bank, 2017).

Like migrants from other places such as Asia and Eastern Europe, African migrants often face restrictive policies, hostile labour market conditions, low wages and institutional discrimination which they struggle to challenge (Jones et al., 2014; Kloosterman, 2010; Kloosterman, Rusinovic and Yeboah, 2016; Wills et al., 2009). To cope with the xenophobic sentiments and discriminatory struggles, some migrants resort to their ethnic affiliations and homogeneous groups or use their resilient mind set and reasoning to shape their enterprise development (Herbert et al., 2008; Kloosterman, Rusinovic and Yeboah, 2016). Utilising their international experience and embedded networks of native countries' institutions, African migrant entrepreneurs develop SMEs in their native countries of origin, but they face weak institutional environments (Chrysostome, 2014; Chrysostome and Lin, 2010).

However, very little is known about how African diaspora overcome constraints and challenges in different institutional contexts, and how they are motivated by the same institutional environments, to embark on enterprise development successfully in their countries of origin. Given the theoretical and contextual discourses of institutional paradoxes (Smith and Tracey, 2016) engrained in diaspora entrepreneurship in their countries of origin, we are able to confirm our propositions that: (i) diaspora entrepreneurs take stimuli from the challenges and prospects of domiciling abroad to 
exploit business opportunities and develop SMEs in their countries of origin and (ii) diaspora entrepreneurs take motivation from informal networks and cultivate resilience for withstanding weak institutions in their countries of origin, to explore and develop SMEs in their native countries. We subsequently validate these through empirical data.

\section{Methods}

We adopted an interpretive approach to understand African diaspora entrepreneurs' motivation and narratives for doing business in Africa and to gather rich data for explaining the distinctive African diaspora entrepreneurs' institutional frames (see Birkinshaw, Brannen and Tung, 2011; Eisenhardt, 1989). Studies that apply an interpretive line of inquiry to investigate underexplored areas of SME development have done so to understand entrepreneurs' intuitions and experiences, and added new theoretical insights to entrepreneurship (Amankwah-Amoah, Boso and AntwiAgyei, 2018; Rae, 2005; Choudrie and Culkin, 2013), or have formed the basis for doing so to the immigrant entrepreneurship strand (Munkejord, 2015). However, we anchored the interpretivist reality of the underexplored African diaspora entrepreneurs' push and pull motivational factors for investing in Africa in the grounded theory methodology, to distil constructs and support theory development. Grounded theory methodology is used to conceptualise phenomena in studies where either theory had not existed or been regarded to be inadequate (Lehmann, 2001; Strauss and Corbin, 2008).

Within a 15-month period from 2015-2017, we were able to identify and interview 15 African diaspora entrepreneurs in the UK with entrepreneurial ventures in Africa, including three people from the same enterprise who constituted a focus group, using different business models. Our choice for 15 participants is supported by evidence from the methodological literature that qualitative research typically employs small sample size (Cassell and Symon, 2004), with 12 interviews sufficient for researchers to achieve saturation and to develop $92 \%$ of total codes required for further data analysis (Guest, Bunce and Johnson, 2006). Substantiating this are 
entrepreneurship research investigations that utilised eight (Crick and Chaudhry, 2013), nine (Munkejord, 2015) and eleven (Giroux, 2009) interviews as the main data collection instruments to achieve their studies' intentions.

Using purposive and snowballing sampling techniques including churches, local diaspora associations and direct referrals, 13 multiple cases of African diaspora entrepreneurs owning and managing SMEs were identified in the services and manufacturing sectors including the one that provided three participants for the focus group discussion. Table 1 provides detailed information about the industrial sectors and background information of the informants.

The multiple cases were drawn from the two enterprise sectors (social enterprise models and forprofit enterprise models) to enhance our investigation into how the similarities and differences between the sectors and the institutional contexts within which they operate in various African countries impact the diaspora entrepreneurship. However, the approach is typical of diaspora entrepreneurship research where cases are drawn from multiple entrepreneurs (Munkejord, 2015; Smallbone et al., 2005) or from one entrepreneur and his associates (Riddle and Brinkerhoff, 2011) to institutional effects and entrepreneurial action.

Four of the cases operated in the social enterprise model category. The activities of the four include: (i) clothes sales to help street boys in Ghana; (ii) healthcare supplies trading to support the healthcare sector in Malawi; (iii) a mobile money-transfer business in Cameroon, Ghana, Kenya, Nigeria and Sierra Leone; and (iv) clothing manufacturing employing artisans in the Gambia, Nigeria and Kenya. The other nine enterprises operated within a for-profit category, but these are classified into two broad categories, i.e. Type 1 and Type 2 to reflect their core operational activities.

Type 1 category consists of five businesses with operational activities spread across areas such as: (i) money transfer from the UK to Ghana and Zimbabwe; (ii) accounting consulting services in the 
UK and Nigeria; (iii) financial consulting in Malawi; (iv) real estate management in Nigeria: and (v) oil and gas services in Nigeria. Broadly speaking, Type 1 category businesses specialise in financial and management consultancy services and charge fees for their expertise. Type 2 category consists of four separate businesses focusing on logistics and delivery from the UK to Nigeria, second-hand car-parts exports from the UK to Ghana and Cameroon, and fashion design in Nigeria. Businesses in the Type 2 category handle more tangible items and therefore differentiate themselves from their Type 1 counterparts.

Semi-structured interview protocol was used to seek participants' understanding of the phenomenon through (i) a focus group of three diaspora entrepreneurs in the Type 1 money transfer business from the UK to Ghana and Zimbabwe and (ii) face-to-face interviews with 12 other individual entrepreneurs across the different forms of businesses. We started the participants' engagement with the focus group discussion to gain deeper insights of the diaspora entrepreneurs' contexts, their motivations and challenges from the perspectives of the Ghanaian and Zimbabwean interviewees. Our rationale was to spark off heterogeneous interactions within the same business that would (i) provide rich and synergistic understanding of what this small group of entrepreneurs had been doing and how they were motivated to succeed in the volatile and risky financial market (see Krueger and Casey 2000) and (ii) unearth the potential themes of enquiry that we could explore deeply through the subsequent face-to-face interviews and to generate rich data (see Lambert and Loiselle, 2008). Mixing the focus group and the face-to-face interviews also gave us the opportunity to triangulate the responses from the two data collection methods and to validate the accuracy and trustworthiness of the data (see Ja"msa, Ta"htinen, Ryan and Pallari, 2011; Yin 2014).

The interviews took place at the diaspora entrepreneurs' places of work and time of convenience. All conversations, except one, were audio recorded. The questions mainly covered the entrepreneurs' motivation and the backgrounds of their businesses; challenges in doing business 
in Africa; the effects of formal and informal institutional factors in the UK and home country on the entrepreneurs' businesses; and their profile information. In addition to the primary data, we also reviewed policy reports and news files on small businesses and institutional impediments faced by diaspora entrepreneurs.

\section{Insert Table 1 about here}

\section{Data analysis, findings and Interpretation}

We followed the "24-hour rule" (Eisenhardt, 1989) to transcribe the interviews verbatim and crosschecked with our field notes to fill gaps. We then compared the individual responses to establish associations that overarched the key interview questions relating to African diaspora institutional challenges and motivations that affect their decisions for business formation and development. By doing this, we were able to capitalise on the immediacy of our data and to develop a clear chronology of their entrepreneurial activities, nature of investments and industry (Gioia and Thomas, 1996). We then employed a narrative strategy (Langley, 1999) by writing a detailed analysis for each participant and supported the interviews data with press and government reports on immigrant entrepreneurship.

Following the grounded theory methodology, we adopted three coding stages - open coding, axial coding and selective coding, to identify and distil the key data constructs (Caprar, 2011, Corbin and Strauss, 1990; Douglas, 2003; Walker and Myrick 2006), with examples illustrated in Appendices 1 and 2. Open coding involves breaking down the data to compare, conceptualise and categorise them into first-order themes (Corbin and Strauss, 1990, p. 61). Here, the participants' descriptions, key terms/phrases, concerns and inspirations were categorised to enable us to identify similar influences and issues of diaspora entrepreneurship from the data. Next, we followed the axial coding, which entailed incorporating the first-order categories into second-order themes to 
establish the interrelated elements of the data (Stoyanov et al., 2018b; Corbin and Strauss, 1990). This led us to set out the interview data into the countries of origin's institutional challenges and motivators and country of residence's (UK's) institutional challenges and motivators, to understand African diaspora entrepreneurs' contexts.

After this stage, we utilised selective coding to aggregate the key institutional factors that pull or push the African diaspora entrepreneurs to make investment decisions, to operate enterprises in the native countries. Selective coding therefore entails integrating and refining categories into themes and inductively utilises the outcomes of the three coding processes to build theory (Strauss and Corbin, 2008). Based on the above analytical approach to data reduction, we uncovered two broad phases of understanding African diaspora institutional contexts in both the country of residence and their countries of origin and, how they cultivate resilience for weak institutional environment and exploit opportunities to develop SMEs in Africa. We narrate our findings and interpretations to illuminate both phases to validate our initial propositions that help us understand the African diaspora entrepreneurs' motivation for starting enterprises in Africa and ground these into new theoretical insights. These also highlight the participant entrepreneurs' voices and reflect stories of their experiences, perceptions and motivations for embarking on SMEs development.

\section{Phase 1 - Diaspora Entrepreneurs' Institutional Challenges and Motivation}

Our analysis of the data suggests that African diaspora entrepreneurs' SME developments are shaped by the institutional factors in their countries of origin as well as country of residence (see also Appendices 1 and 2).

\section{Countries of origin's institutional challenges and weaknesses}

The bureaucratic formal institutional structures of African diaspora's countries of origin increasingly present multifaceted problems for them and their businesses generally. The data 
highlight a long list of these issues including weak and unsupportive bureaucratic government institutions, lack of access to good-quality information, large proportion of unskilled labour and poor work ethics. Some entrepreneurs complained about government bureaucracies and hierarchical administrative layers that encourage poor regulatory regimes, and delay company registration processes, decision making and project delivery times. On company registration process, a fashion design entrepreneur recounted his experience in Nigeria by noting in the semistructured interview:

"Registering a company is supposed to be a straightforward process but because of inefficiencies in the system ... this process can take you more than two or three weeks."

Comparing the situation in Cameroon with Ghana, Nigeria and Côte d'Ivoire Second-hand carparts dealer 2 argued that bureaucracy from customs and excise in Cameroon are the worst and it could take a month or more to pass through a hurdle of bureaucracies before getting the exported goods to Cameroon cleared. Connected with this are unclear customs and excise laws, lengthy and frustrating clearing processes, and differential clearing fees for identical consignments that discourage exportation of tangible goods such as second-hand car parts from the UK.

Furthermore, bribery, corruption and extortion by unscrupulous public officials is deeply entrenched in all institutions that provide support from government officials. Almost all participants agreed that paying such monies would increase their costs of doing business and not paying would delay business activities "forever". Drawing on his 25 years' experience, during the semi-structured interview Second-hand car-parts dealer 1 from Ghana criticised the customs and excise regulations and the way they are managed as being corrupt and discriminatory:

"The duty and the tax system are not fair in the sense that 3,4 or 5 people can bring the same container, but one can clear his by paying less, others more or even to use a middleman with far more costs."

Even though corruption is a challenge, some entrepreneurs expressed the view that, it should not discourage their desire and motivation for running SMEs in their countries of origin because it is a general issue that happens in other parts of the world, and not only Africa. In the focus group 
discussion, Money-transfer entrepreneur 2 from Zimbabwe noted this about the perception of corruption on Africa:

"I don't believe that the Western culture is free of the perception of corruption or corruption itself either. While people may describe it as something else, it is exactly the same thing because when you hear about members of parliament and expenses scandal, you start to ask questions. I speak about it passionately because ... I'm not naive to think that it is an African phenomenon; it is not... But I don't grease the palm, full stop"

On this issue, an oil and gas entrepreneur from Nigeria concurred during the interview:

"I think it is not just particular to Nigeria or West Africa. You know gifts, inducements, how you categorise it, vary from culture to culture. In certain cultures, it is more acceptable to provide gifts as inducement or encouragement...I think it depends on the nature of the gift, the appropriateness and the circumstances. If it is part of the business development drive, then I see that, it can be probably legitimate to provide gifts."

However, the difference is that culprits are legally prosecuted and sentenced in the Western culture. Yet, in much of Africa, due to the weaknesses of legal institutions politicians do it with impunity. Perhaps the oil and gas entrepreneur's point on how cultural norm could be used to delineate gifts, inducements and their legitimacy in entrepreneurship, seems far more important for clarifying the nature and circumstances of gifts when procuring enterprise formation and development in an informal relationship context such as Chinese Guanxi (see Fan, 2002; Peng et al., 2009). It is pertinent to state that none of our participants condoned corruption, but they sought to remain firm and focus when operating in corrupt and weak institutional environments.

Institutional weaknesses were also revealed through a lack of robust personal identification (ID) systems in many African countries for tracking citizens' details. This created difficulties for the money transfer enterprises because it caused delays at the receiving end where the beneficiaries had to produce genuine IDs before being paid their remittances. Money-transfer entrepreneur 3 from Zimbabwe who operates businesses in both Zimbabwe and Ghana articulated the problem in the focus group discussion as:

"Traditionally not everyone in Africa has got an ID. And now we are on the receiving end of the after-effect of money laundering and counter-terrorism. Maybe we might have a bit of wriggle with money transfer because the regulations are becoming a lot stricter." 
The data suggests that poor work ethics and ineptitude of the population and public officials in the host countries undermined enterprise development in Africa. Comparing this laid-back work culture to the attitude to work in the UK, Money-transfer entrepreneur 1 noted the following in the focus group discussion:

"I know if it starts raining a lot of people will call their bosses to say that they would not go to work but here, even when it is raining you have to pick your bag and go to work."

Second-hand car-parts dealer 1 confirmed this irresponsible attitude as:

"In Ghana, sometimes, when it rains, they don't go to work because they are not serious and the commitment to go to work is not all that strong. So, we cannot compare attitudes of public servants to work here (UK) to that in Ghana".

It is also worth noting that this is not just because of attitude, but also has to do with formal institutional weaknesses relating to relaxed rules and policies on employees' time management in public sector organisations which allow employees to provide constant excuses for absenteeism (see Abugre, 2017).

However, Money-transfer entrepreneur 3 noted that there are very hardworking people in African countries:

"In our company the culture and attitude towards work here (UK) is what has been transplanted to Ghana. We have staff members that work as hard as we do here (UK), they are committed. I think they work harder because they cover all the weekends and on some banks holidays for the calls that we get"

Macroeconomic worries arising from fluctuating exchange rates, higher interest and tax rates, and rising inflation rates also slow entrepreneurial activities for all types of businesses engaged in the study. To the consultancy firms, accounting consulting entrepreneur cited the difficulty involved in charging fees in advance before delivering service or filing statutory documents for clients as a challenge because rising inflation and exchange rates fluctuations reduce the value of money paid later by clients. For entrepreneurs dealing with distribution of tangible goods such as the case of the Logistic and delivery entrepreneur, the weak infrastructure base such as poor roads and traffic congestion impede quick stock turnover while those in ICT service provision complained about inadequate internet and power supply. 


\section{The UK's institutional challenges for African diaspora}

Some diaspora entrepreneurs were constrained by unemployment in the UK, leading them to establish self-employed enterprises, as experienced by an Accounting consulting entrepreneur. Others were also out-competed by their inabilities to cope with the UK hi-tech economy which requires a growing knowledge of digital skills as explained by Second-hand car parts dealer 2, leading to frustrated career advancement for diasporas who had to upgrade their technological skills.

The data shows that, the diaspora entrepreneurs faced institutional discrimination and glass ceiling, but they were able to withstand the challenges and turn misfortunes into business opportunities in Africa. For others, as explained by a Real estate entrepreneur, stiff competition in the Western market thwarted their business activities in the UK where they had little to no business networks with the indigenes. Second-hand car parts dealer 2 put this in the interview as:

\footnotetext{
"The main challenge is the societal class and differences, in terms of a Blackman doing business in a Whiteman's country. There is that natural chemistry that Black goes to Black and White goes to White, so doing business here is difficult and succeeding is usually one out of a lot."
}

The interpretation of the data reveals that, these challenges persuaded some diaspora entrepreneurs to diversify into, and focus on, sub-Saharan Africa business engagements.

\section{Countries of origin's motivational factors for African diaspora}

One common response across all the interviewees is that the African formal institutional environment is weak even in places where there are socio-political stability and improved macroeconomic environments, as noted in the previous section. In spite of these formal institutional challenges, some of the African diaspora entrepreneurs are motivated by a number of informally embedded institutional factors in their countries of origin. In addition to family and personal ties which diaspora entrepreneurs exploit for informal credits and local business knowledge, they identify other trusted business partners such as the clientele referral networks in the African 
markets. This was noted as a very important way to collaborate with partners with whom the entrepreneurs had no prior relations, particularly in social enterprises and Type 1 for-profit businesses which rely more on entrepreneurs' skills and expert knowledge.

Resources such as ideas and trust of family and kinship networks appears to play a pivotal role. On this, the financial consulting entrepreneur from Malawi reiterated the importance of family contribution in his business, particularly in his absence where ideas and the support from family had been immensely beneficial:

"I rely on the family to progress my business, they give me advice and are doing the footwork, finding the clients and helping me to understand the pros and cons. They are in the position to know the market better than I do and I do trust them."

The data indicates that trust in family members is paramount inspiration and a source of support for African diaspora entrepreneurs' business development. However, it is worth noting that, the role of family and kinship ties in facilitating diaspora entrepreneurship is complex because of elements of dishonesty in such networks which can hinder entrepreneurship (see Amoako and Lyon, 2014). Social entrepreneur 1 made it clearer during the interview that not all family members could be trusted:

"I had to rely on my parents because it's more of trust; there are other close family members, but I wouldn't get them involved because I don't think they are honest enough to be involved in the business. So, it is more of trust and being able to distinguish between honest and trustworthy members of the family and those who are not and using the former."

Apart from lack of trustworthiness, many of the entrepreneurs considered some family norms to be a constraint to entrepreneurship in Africa. A real estate entrepreneur discussed his dilemma in during the interview in this way:

"When the person is older than you, then African culture comes into place and you can't assert yourself; there is a way you are supposed to talk to them even though you guys are business partners. Cultural norms that demand respect for the elderly and seniors make it difficult to work with family members who are older than myself because it is difficult for the younger partner to rebuke the senior partner should he make wrong moves" 
Notwithstanding the constraints of the family, the overwhelming majority agree that family/kinship can facilitate and enhance business development particularly for the diaspora entrepreneurs since they cannot be physically present in their home countries most of the time. Apart from family and kinship ties, friendships and other network ties are equally important for the entrepreneurs. Accounting consulting entrepreneur stated that his business is dependent on networks of clients which were mainly created through a word-of-mouth referral:

"Most of the clients we have ... came through referrals...that's how we get them, and you need to maintain good business relations with them so that the trade does not collapse."

Similarly, the Money-transfer entrepreneur 3 emphasised the relevance of networks as a motivator for effective business management in Africa:

"If you are somebody who does not have that network or connection, it is going to cost you a lot of money to run such business in Africa."

\section{The UK's institutional motivation for African Diaspora}

The data shows that, the diaspora entrepreneurs were also encouraged by the institutional environments of the UK that allow them to receive higher earnings as well as achieving higher levels of business knowledge and skills, obtained through academic studies, enterprise support institutions, formal paid or unpaid work experience and self-employed initiative. During the interview Social entrepreneur 3 elaborated his motivation from the more reliable UK formal institutions in the following account:

"I got some of my knowledge and learning from university but also inspiration from listening to and reading the news and seeing some of the entrepreneurs and understanding their life stories equally inspire me."

This knowledge has, to some extent, given them the zeal and tenacity to endure the numerous challenges they face in the UK and have been able to turn such challenges into business opportunities in Africa. The existence of good business and work ethics, fairer and more transparent tax systems, stable macroeconomic environments and enterprise supporting 
institutions in the UK were all cited by the entrepreneurs as factors that influenced the diaspora entrepreneurs to establish enterprises in Africa.

\section{Phase 2 - Diaspora Entrepreneurs' Institutional Challenges and Motivation}

The participants' narratives emanating from Phase 1, indicate that institutional contexts affect the behaviour and actions of African diaspora entrepreneurs and the progress they make in SMEs development in Africa. Comparing with their countries of origin, the diaspora entrepreneurs rated the general economic and business environment as better in the UK, with a strong and healthier government, better and more reliable enterprise-supporting institutions, fairer and more transparent tax systems, better educational systems, and better business and work ethic. At the micro level, the entrepreneurs were specifically motivated by the higher levels of income that households received for supplying their economic factors of production and which gave diaspora entrepreneurs the opportunity to earn income and remit some to support their SME developments in Africa. Combining the enhanced knowledge and skills they had gained by living in the UK and the motivation they derived from the supportive informal structures in their countries of origin, the diaspora entrepreneurs felt that they had developed substantial experience and personal innovativeness to help them succeed in life. Given their individual experiences, resilience and understanding of the local markets, they were confident that they were able to overcome the unwelcoming environments abroad and the weak formal institutions at home, and to start different types of SMEs in their countries of origin. We frame these insights through our Diaspora Entrepreneurs' Motivation for Enterprise Development (DEMED) model, as illustrated in Figure 1 and discussed as follows:

Insert Figure 1 about here 
Our analysis thus far suggests that diaspora entrepreneurs use their local knowledge as assets for doing business in home countries. They take great stimuli from the strong family ties and personal networks that are embedded in the informal institutions and social norms of their countries of origin (M1) when pursuing enterprise development in home countries. They augment these pull factors with better educational opportunities, strong work ethics and prospects of obtaining higher earnings from working in the strong formal institutions established in the UK, in this case their Western country of residence (M2), which enable them to exploit business development at home. The Fashion design entrepreneur explained the dynamics of earning income from work in the UK (pre-migration pull factor) and saving some to run a family-supported business at home (postmigration pull factor) as follows:

"Compared to Africa when I had a job my income was very good and I was able to make some savings and so when I was made redundant I used it as capital for my business back home which is supported by family members"

Diaspora entrepreneurs' ability to set up enterprises and operate flourishing business ventures also depends on their resilience to hostile macro environments characterised by the weak formal institutions, corruption and insufficient enterprise funding opportunities in their countries of origin (C1). These home country challenges add to the entrepreneurs' determination to endure the discriminatory institutional obstacles, glass ceiling and career frustrations they face in the country of residence $(\mathrm{C} 2)$. We explain the broader institutional challenges as macro-level problems that can potentially hinder immigrants' progress in the country of residence or impede their enterprise development activities in the country of origin. These include red tape in transaction flows and limited funding issues which align with $(\mathrm{C} 1)$ challenges.

Nevertheless, many immigrants are innovative individuals who undertake self-employment as a fall-back option to survive glass ceilings and career frustration challenges $(\mathrm{C} 2)$ in the country of residence. Self-employment options create prospects for diaspora entrepreneurs to develop 
business skills development and accumulate personal savings which they eventually rely on to set up their businesses in their countries of origin. The diaspora entrepreneurs therefore garner their personal innovativeness to turn challenging situations abroad into business development opportunities back home. The Nigerian events entrepreneur shared his experience of being innovative and changing his options to avoid the challenging and discriminatory institutional landscape:

"It is difficult to get a job here as an events manager and even if I start my own business here it is very difficult to survive because I am black and so starting my business in Africa was a good thing for me".

The events manager's narrative also indicates that diaspora entrepreneurs are motivated to operate successful business in their countries of origin. For many, their motivations are to support community development, improve maternal healthcare, develop the lives of street children, empower women's access to mobile technology, support family and friend, facilitate secured remittance of immigrants' money, transfer knowledge to the Global South formal settings, and improve growth in Africa. Table 1, column 7, highlights some of the African diaspora motivations for developing enterprises in Africa, with the Nigerian accountancy entrepreneur indicating that diaspora unemployment in the UK encouraged his decision to set up self-employed accountancy firm.

In summary, the DEMED model explains that diaspora entrepreneurs are motivated by their ability to obtain informal credits and use local knowledge from family ties and personal networks to enrich business development in their countries of origin. The model provides the understanding that diaspora entrepreneurs can simultaneously take motivations from the challenges and prospects of living abroad to develop SMEs in their countries of origin as well as using informal networks and fostering resilience to withstand weak institutional environments in their countries of origin, to develop business enterprises. 


\section{Discussions}

This article sought to conceptualise how institutional factors in African diaspora entrepreneurs' countries of origin as well as in their countries of residence motivate them to explore and exploit business opportunities in their countries of origin. Using insights from African diaspora entrepreneurs in the UK, the study indicates that entrepreneurs recognise the myriad of institutional constraints such as government bureaucracy, corruption and weak legal systems, which apparently deter non-native African investors (Chrysostome, 2014; also see Zoogah et al., 2015), as contours that they navigate before exploring enterprise opportunities in Africa. However, we agree with others (Brinkerhoff, 2016; Riddle and Brinkerhoff, 2011) that diaspora entrepreneurs often take concessions in the supporting networks from family, kinship and personal ties, as assets that enable them to circumnavigate the formal institutional barriers and exploit the promising business opportunities successfully in African economies, and other emerging markets.

Indeed, diaspora entrepreneurship and its institutional contexts are complex (Rana and Elo, 2017; Stoyanov et al., 2018b), and the notion that formal institutions in developing economies promote entrepreneurship is too simplistic. It requires a deep understanding of diaspora entrepreneurs' contexts, their challenges and intricacies, and tenacity of the entrepreneurs to manage institutional constraints and dilemmas that affect their decisions to invest in emerging countries. The narratives of this study indicate that African diaspora entrepreneurs are motivated agents of development, as similarly observed elsewhere (Stoyanov et al., 2018b), who can withstand precarious institutional environments, both in abroad and at home, and mobilise resources and networks to develop SMEs in Africa.

Our analysis also demonstrated that institutional barriers which encouraged or forced migrants to leave their 'home' countries to seek greener pastures abroad may later become pull factors for those who acquired new knowledge and skills, and wealth to return to their countries of origin to 
invest and start new ventures. This comes to explain the tensions and paradoxes in both entrepreneurship and institutional contexts which act as push and pull factors of enterprise development (Mani 2004; Dodd and Anderson, 2001; Smith and Tracey, 2016), and which the diaspora entrepreneurs experience and explore in context to drive their business initiatives.

Taken together, and contrary to the established assumptions that there is limited economic growth in countries with weak institutions (see Peng, 2014), African diaspora entrepreneurs are able to collaborate with trusted family members and other personal and business networks to run successful businesses and contribute to African SMEs development. This can be explained since institutions will not necessarily constrain entrepreneurship if diaspora entrepreneurs are determined to manage the contextual paradoxes while remaining resilient to hostile institutional environments. Entrepreneurs, as agents, have the capacity to envisage new alternatives and innovate in order to successfully operate their businesses (Amankwah-Amoah et al., 2018; Garud et al., 2007; Villares-Varela et al., 2018).

\section{Conclusion}

In this article, we draw on the institution-based theories and the grounded theory methodological approach to theorise diaspora entrepreneurs' institutional environments that serve as pull and push factors in the African diaspora entrepreneurs' countries of residence and origin, to motivate them to invest in their countries of origin. From a theoretical standpoint, the study has applied institution-based views to develop the DEMED model to explain how diaspora entrepreneurs take stimuli from the challenges and prospects of living abroad to exploit and develop SMEs in their countries of origin. It further expounds on the ways these entrepreneurs take motivations from informal networks and cultivate the spirit of withstanding weak institutions at home, as they engage in enterprise developments and change initiatives. The insights from this study highlight the significance of informal institutions such as personal networks and trust in diaspora 
entrepreneurship growth in Africa. Thus, the findings support the view that native entrepreneurs can rely on trust, personal networks and cultural proximities to grow firms in weak formal institutions (see Amoako, Akwei and Damoah, 2018; Amoako and Lyon, 2014; Zhu et al., 2011).

Though our contribution complements the existing knowledge that diaspora entrepreneurs can draw on their international experience and resources to develop businesses and contribute towards economic development in their countries of origin (Heitor, Horta and Mendonça, 2014; Rana and Elo, 2017; Riddle and Brinkerhoff, 2011), it is distinct in the way that it explores diaspora entrepreneurs' motivations and challenges from two dissimilar geographical regions and interact them to bring new insights to entrepreneurship. By applying institution-based frames to explicate African diaspora entrepreneurs' role in supporting SMEs development in Africa, we have generated discussions of entrepreneurship paradoxes that introduce other consideration to the broader diaspora entrepreneurship discourse. We have noted that: (i) the precarious environments that drive the diaspora out of their native countries later become lucrative grounds for business enterprise, with their associated formal institutional weaknesses; (ii) the Western country of residence provides opportunities for diaspora entrepreneurs but they confront institutional discrimination; and (iii) family and kinship ties provide support for diaspora entrepreneurs' businesses but dishonesty of some informal ties constrain enterprise development.

The study has demonstrated that we can approach the complexities and paradoxes surrounding diaspora entrepreneurship by theorising the subject intrinsically and jointly from the country of residence and countries of origin, as professed by our DEMED model in Figure 1. This will allow the entrepreneurs to utilise the pull and push diaspora immigrants' institutional factors innovatively and to develop the entrepreneurial resilience needed for turning institutional constraints into assets (see Amankwah-Amoah and Debrah, 2017; van Burg and Romme, 2014). By this, we have responded to Zoogah et al. 's (2015) call for researchers to use African context to extend and build new theories with empirical validity that enlighten the role of institutions in 
African entrepreneurship, ones where the DEMED model can play an effective role to unearth diaspora entrepreneurs' intrinsic motivations and innovativeness and help them succeed in business ventures.

From a practical standpoint, diaspora entrepreneurs can capitalise on their international experience and knowledge to explore, exploit and facilitate business opportunities in their native countries (see Riddle and Brinkerhoff, 2011). Given the precarious nature of the formal institutional environments particularly in their countries of origin, the entrepreneurs should be encouraged to rely on their agencies as well as social networks including family, kinship, personal and business ties to establish and manage successful businesses. One way of doing this is to develop a digital platform of diaspora SMEs ecosystem that can enable them to innovate their informal institutional support and to overcome the challenges with the weak formal institutions. This will also serve as a platform for creating valid knowledge of entrepreneurial resilience and learning that can help them manage hostile environments in the countries of origin and use their entrepreneurial spirit to foster business development programmes in their countries of origin. It is also worth noting that overreliance on informal networks and family members may not guarantee long-term success due to lack of trustworthiness and complacent behaviours that allow strategic errors to occur. With international experience, the diaspora entrepreneurs can infuse outside expertise and joint ventures that can improve their competitiveness and create employment opportunities for people (see Rana and Elo, 2017; Stoyanov et al., 2018b).

From a public policy perspective, there is a need for governments in countries of origin to initiate programmes geared towards encouraging the diaspora population to return to establish new businesses and foster transfer of technological and entrepreneurial competences (NkongoloBakenda and Chrysostome, 2013). One implication is that diaspora entrepreneurs' investments can foster job creation and enterprise development in underserved communities often ignored by large investors and multinationals. In particular, as diaspora social entrepreneurs often focus on 
deprived communities and given that social entrepreneurs rely more on grants, which are relatively more financially constrained (Lyon and Baldock, 2014), there is the potential for them to be demotivated by bureaucracy, red tape and corruption. Policy programme on diaspora investment management is therefore necessary to motivate and safeguard diaspora entrepreneurs' investments in the countries of origin (Brinkerhoff, 2016) while talent initiatives can also be developed by the home governments to motivate migrants to return home (Logan, 2009).

We observe, for instance, that diaspora entrepreneurs who deal in physical goods often encounter demands for bribes particularly from customs officials at the ports and therefore incur additional costs which may eventually be passed on to consumers. Taking a firm line on challenging and curbing bribery and corruption will therefore be necessary for diaspora investments in home countries. Doing this would bring some confidence and certainties in African entrepreneurship, create an opportunity for foreign investments and enable knowledge diffusion from Western contexts to emerging economies (Chrysostome, 2014; Radwan and Sakr, 2018).

While our study provides theoretical and practical perspectives on diaspora entrepreneurship, it is necessary to confine its scope for generalisability to African diaspora in the UK and diaspora entrepreneurship in Africa to reflect the two geographical contexts of focus. In future, researchers could apply the study's theoretical development to explore the relationships between African diaspora entrepreneurs' motivation or resilience for doing business in home countries and their levels of success through quantitative investigations. In addition, given the geographical distance between home and host countries and the changing institutional contexts, it would be useful to examine whether diaspora entrepreneurs would overtime remain resilient to the complex and volatile environments within which they operate.

\section{References}

Abrutyn, S., Van Ness, J., 2015. The role of agency in sociocultural evolution: Institutional entrepreneurship as a force of structural and cultural change. Thesis Eleven, 127(1), 52-77. 
Abugre, J. B., 2017. A phenomenological study of time concept and management and productivity in a sub-Saharan African context. International Journal of Cross Cultural Management, 17(2), 197-214.

Adomako, S., Amankwah-Amoah, J., Dankwah, G. O., Danso, A., \& Donbesuur, F. (2019). Institutional voids, international learning effort and internationalization of emerging market new ventures. Journal of International Management, 25(4), 100666.

Aharoni, Y., 1966. The Foreign Investment Decision Process, Boston: Harvard Graduate School of Business Administration, Division of Research.

Amankwah-Amoah, J. 2016. The evolution of science, technology and innovation policies: A review of the Ghanaian experience. Technological Forecasting and Social Change, 110, 134-142.

Amankwah-Amoah, J., Debrah, Y., 2017. Toward a construct of liability of origin. Industrial and Corporate Change, 26(2), 211-231.

Amankwah-Amoah, J., Debrah, Y., Nuertey, D., 2018. Institutional legitimacy, cross-border trade and institutional voids: Insights from the cocoa industry in Ghana. Journal of Rural Studies, 58, 136-145.

Amankwah-Amoah, J., Boso, N., Antwi-Agyei, I., 2018. The effects of business failure experience on successive entrepreneurial engagements: An evolutionary phase model. Group \& Organization Management, 43(4), 648-682.

Amankwah-Amoah, J., Hinson, R.E. 2019. Contextual influences on new technology ventures: A study of domestic firms in Ghana. Technological Forecasting and Social Change, 143, 289296.

Amankwah-Amoah, J., Chen, X., Wang, X., Khan, Z., \& Chen, J., 2019. Overcoming institutional voids as a pathway to becoming ambidextrous: The case of China's Sichuan Telecom. Long Range Planning.

Amoako, I.O., Akwei, C.A. and Damoah, I .2018. We Know their House, Family and Work place:Trust in Entrepreneurs' Trade Credit Relationships in Weak Institutions, Journal of Small Business Management, DOI: 10.1111/JSBM.12488.

Amoako, I. O., 2018. Trust, Institutions and Managing Entrepreneurial Relationships in Africa. Springer.

Amoako, I. O., Lyon, F., 2014. 'We don't deal with courts': Cooperation and alternative institutions shaping exporting relationships of small and medium-sized enterprises in Ghana. International Small Business Journal, 32(2), 117-139.

Basu, A., 1998. An exploration of entrepreneurial activity among Asian small businesses in Britain. Small Business Economics, 10(4), 313-326.

Beck, T., Dermirguc-Kunt, A. \& Maksimovic, V., 2005) Financial and legal constraints to growth: does firm size matter?. The Journal of Finance, 60 (1), 137-177.

Bendapudi, N., Leone, R. P., 2002. Managing business to-business customer relationships following key contact employee turnover in a vendor firm. Journal of Marketing, 66, 83101.

Bendickson, J., Muldoon, J., Liguori, E., Davis, P. E., 2016. Agency theory: the times, they are achangin'. Management decision, 54(1), 174-193

Birkinshaw, J., Brannen, M. Y., Tung, R. L., 2011. From a distance and generalizable to up close and grounded: Reclaiming a place for qualitative methods in international business research. Journal of International Business Studies, 42(5), 573-581.

Bratton, M., 2007. Formal versus informal institutions in Africa. Journal of Democracy, 18(3), 96-110.

Brinkerhoff, J. M., 2016. Institutional Reform and Diaspora Entrepreneurs: The In-Between Advantage. Oxford University Press. 
Bruder, J., Räthke-Döppner, S., 2008. Ethnic minority self-employment in Germany: geographical distribution and determinants of regional variation (No. 100). Thünen-series of applied economic theory.

Bruton, G. D., Ahlstrom, D., Li, H. L., 2010. Institutional theory and entrepreneurship: where are we now and where do we need to move in the future? Entrepreneurship Theory and Practice, 34(3), 421-440.

Caprar, D. V., 2011. Foreign locals: A cautionary tale on the culture of MNC local employees. Journal of International Business Studies, 42(5), 608-628.

Cavusgil, T., Ghauri, P., Agarwal, M., 2002. Doing business in emerging markets: Entry and negotiation strategies. Thousand Oaks: Sage.

Chand, M., 2016. Leveraging the diaspora for Africa's economic development. Journal of African Business, 17(3), 273-290.

Cheung, G. C., 2004. Chinese diaspora as a virtual nation: Interactive roles between economic and social capital. Political Studies, 52(4), 664-684.

Chrysostome, E. \& Lin, X., 2010. Immigrant entrepreneurship: Scrutinizing a promising type of business venture. Thunderbird International Business Review, 52(2), 77-82.

Chrysostome, E., 2010. The success factors of necessity immigrant entrepreneurs: In search of a model. Thunderbird International Business Review, 52(2), 137-152.

Coniglio, N. D. \& Brzozowski, J., 2016. Migration and development at home: Bitter or sweet return? Evidence from Poland. European Urban and Regional Studies, 25(1), 85-105.

Corbin, J. M. \& Strauss, A., 1990. Grounded theory research: Procedures, canons, and evaluative criteria. Qualitative Sociology, 13(1), 3-21.

Corbin, J. M. \& Strauss, A., 2008. Basics of qualitative research: Techniques and procedures for developing grounded theory.

Crick, D. \& Chaudhry, S., 2013. An exploratory study of UK based, family-owned, Asian firms' motives for internationalising. Journal of Small Business and Enterprise Development, 20(3), 526-547.

Cuhls, K., 2007. From my (German) Perspective: The brain drain problem, Technological Forecasting and Social Change, 74, 708-714.

Dana, L. P., 2007. Handbook of Research on Ethnic Minority Entrepreneurship: A CoEvolutionary view on Resource Management. Cheltenham: Edward Edgar Publishing.

Das, S. S., Das, A., 2014. India shining? A two-wave study of business constraints upon micro and small manufacturing firms in India. International Small Business Journal, 32(2), 180-203.

De Carolis, D. M., Yang, Y., Deeds, D. L., Nelling, E., 2009. Weathering the storm: The benefit of resources to high-technology ventures navigating adverse events. Strategic Entrepreneurship Journal, 3(2), 147-160.

Diamantides, N. D., 1992. The Macrodynamics of International Migration as a sociocultural Diffusion process, Part A: Theory. Technological Forecasting and Social Change, 42, 273 289

Dodd, S. D., Anderson, A. R., 2001. Understanding the Enterprise Culture Paradigm: Paradox and Policy. The International Journal of Entrepreneurship and Innovation, 2(1), 13-26.

Douglas, D., 2003. Grounded theories of management: A methodological review. Management Research News, 26(5), 44-52.

Eisenhardt, K. M., 1989. Building theories from case study research. Academy of Management Review, 14, 532-550.

Garud, R., Hardy, C., Maguire, S., 2007. Institutional Entrepreneurship as Embedded Agency: An Introduction to the Special Issue. Organization Studies, 28(7), 957-96

Gillespie, K., Riddle, L., Sayre, E., Sturges, D., 1999. Diaspora interest in homeland investment. Journal of International Business Studies, 30(3), 623-634.

Gioia, D. A., Thomas, J. B., 1996. Identity, image, and issue interpretation: Sensemaking during strategic change in academia. Administrative Science Quarterly, 41, 370-403. 
Giroux, I., 2009. Problem solving in small firms: An interpretative study", Journal of Small Business and Enterprise Development, 16(1), 167-184.

Guest, G., Bunce, A., Johnson, L., 2006. How many interviews are enough? An experiment with data saturation and variability. Field Methods, 18, 59-82

Hardy, J., Shelley, S., Calveley, M., Kubisa, J., Zahn, R., 2014. Scaling the mobility of health workers in an enlarged Europe: An open political-economy perspective. European Urban and Regional Studies, 23(4), 798-815.

Harris, J. R., Todaro, M. P., 1970. Migration, unemployment and development: a two-sector analysis. American Economic Review, 60(1), 126-142.

Heitor, M., Horta, H., Mendonça, J., 2014. Developing human capital and research capacity: Science policies promoting brain gain. Technological Forecasting and Social Change, 82, 6-22.

Herbert, J., May, J., Wills, J., Datta, K., Evans, Y., McIlwaine, C., 2008. Multicultural living? Experiences of everyday racism among Ghanaian migrants in London. European urban and regional studies, 15(2), 103-117.

Hoegl, M., M. Gibbert, and Mazursky, D., 2008. Financial constraints in innovation projects: When is less more? Research Policy, 37(8), 1382-1391.

Ja"msa, P., Ta"htinen, J., Ryan, A. \& Pallari, M., 2011), Sustainable SMEs network utilization: the case of food enterprises. Journal of Small Business and Enterprise Development, 18(1), 141-156.

Jones, T., Ram, M., Edwards, P., Kiselinchev, A., Muchenje, L., 2014. Mixed embeddedness and new migrant enterprise in the UK. Entrepreneurship \& Regional Development, 26(5-6), 500-520.

Katila, R., Shane, S., 2005. When does lack of resources make new firms innovative? Academy of Management Journal, 48(5), 814-829.

Kloosterman, R., 2010. Matching Opportunities with Resources: A Framework for Analysing (Migrant) Entrepreneurship from a Mixed Embeddedness Perspective. Entrepreneurship and Regional Development 22 (1): 25-45.

Kloosterman, R. C., Rusinovic, K., Yeboah, D., 2016. Super-diverse migrants-similar trajectories? Ghanaian entrepreneurship in the Netherlands seen from a Mixed Embeddedness perspective. Journal of Ethnic and Migration Studies, 42(6), 913-932.

Kloosterman, R., Van Der Leun, J., Rath, J., 1999. Mixed embeddedness: (in) formal economic activities and immigrant businesses in the Netherlands. International Journal of Urban and Regional Research, 23(2), 252-266.

Krueger, R.A. \& Casey M.A., 2000. Focus Groups: A Practical Guide for Applied Research, 3rd ed. Thousand Oaks, CA, Sage Publications.

Lambert, S.\& Loiselle, C., 2008. Combining individual interviews and focus groups to enhance data richness. Journal of Advanced Nursing. 62 (2), 228-237.

Langley, A., 1999. Strategies for theorizing from process data. Academy of Management Review, 24(4), 691-710.

Lehmann, H., 2001. Using grounded theory with technology cases: Distilling critical theory from a multinational information systems development project. Journal of Global Information Technology Management, 4(1), 45-60.

Logan, B. I., 2009. The reverse and return transfer of technology (RRTT): towards a comprehensive model of the migration of African experts. International Migration 47(4): 93-127

Lu, X., Zhang, W., 2015. The reversed brain drain: a mixed-method study of the reversed migration of Chinese overseas scientists. Science, Technology and Society, 20(3), 279-299.

Lyon, F., Baldock, R., 2014. Financing Social Ventures and the Demand for Social Investment. Third Sector Research Centre Working Paper. Birmingham: Third Sector Research Centre 
Mani, S., 2004) Institutional support for investment in domestic technologies: An analysis of the role of government in India, Technological Forecasting and Social Change, 71, 855-863

Manning, K., Birley, S. \& Norburn, D., 1989. Developing a new ventures strategy. Entrepreneurship: Theory and Practice, 14(1), 68-76.

Massey, D. S., 1998), Worlds in motion: Understanding international migration at the end of the millennium. New York, Oxford University Press.

Mohan, G., Zack-Williams, A. B., 2002. Globalisation from Below: Conceptualising the Role of the African Diasporas in Africa's Development. Review of African Political Economy, 92, 211-236

Munkejord, M. C., 2017. Local and transnational networking among female immigrant entrepreneurs in peripheral rural contexts: Perspectives on Russians in Finnmark, Norway. European Urban and Regional Studies, 24(1), 7-20.

Naudé, W., Siegel, M., Marchand, K., 2017. Migration, entrepreneurship and development: critical questions. IZA Journal of Migration, 6(1), 5.

Ndhlovu, T. P., Ndinda, C., 2017. Social Entrepreneurship in South Africa: A Critical Analysis of Diaspora Social Investments. In Ojo, S. (Ed), Diasporas and Transnational Entrepreneurship in Global Contexts, pp. 219-235

Newland, K., Tanaka, H., 2010. Mobilizing diaspora entrepreneurship for development. Washington, DC: Migration Policy Institute.

Nielsen, T. M., Riddle, L., 2007. Why do diasporas invest in their homelands? A conceptual model of investment motivation. Paper presented at the Academy of Management annual meeting. Philadelphia, PA.

Nielsen, T. M., Riddle, L., 2010. Investing in peace: The motivational dynamics of diaspora investment in post-conflict economies. Journal of Business Ethics, 89, 435-448.

Nkongolo-Bakenda, J. M., Chrysostome, E. V., 2013. Engaging diasporas as international entrepreneurs in developing countries: In search of determinants. Journal of International Entrepreneurship, 11(1), 30-64.

North, D. C., 2012. Understanding the process of economic change. In Worlds of Capitalism (pp. 107-120. Routledge.

North, D.C., 1990), Institutions, Institutional Change and Economic Performance, Cambridge University Press, Cambridge.

Ojo, S., Nwankwo, S., Gbadamosi, A., 2013. African diaspora entrepreneurs: navigating entrepreneurial spaces in 'home' and 'host' countries. International Journal of Entrepreneurship and Innovation, 14(4), 289-299.

Palmer, C. A., 2000. Defining and studying the modern African diaspora. The Journal of Negro History, 85(1-2), 27-32.

Parker, R., 2010. Evolution and change in industrial clusters: An analysis of Hsinchu and Sophia Antipolis. European Urban and Regional Studies, 17(3), 245-260.

Peng, M. W., 2014. Global Business. 3rd edition. Cincinnati: Cengage Learning.

Peng, M. W., Sun, S. L., Pinkham, B., Chen, H., 2009. The institution-based view as a third leg for a strategy tripod. Academy of Management Perspectives, 23(3), 63-81.

Plaza, S., Ratha, D., 2011. Diaspora harnessing resources for Africa, In Plaza, S. and Ratha, S. (Eds) Diaspora for Development in Africa, The World Bank, Washington, D.C.

Radwan, A. \& Sakr, M., 2018. Exploring 'brain circulation' as a concept to mitigate brain drain in Africa and improve EU-Africa cooperation in the field of science and technology. South African Journal of International Affairs, 25(4), 517-529.

Rana M., B. \& Elo M (2017) Transnational diaspora and civil society actors driving MNE internationalisation: The case of Grameenphone in Bangladesh. Journal of International Management 23(1): 87-106.

Riddle, L., Brinkerhoff, J., 2011. Diaspora entrepreneurs as institutional change agents: The case of Thamel. com. International Business Review, 20(6), 670-680. 
Riddle, L., Hrivnak, G. A., Nielsen, T. M., 2010. Transnational diaspora entrepreneurship in emerging markets: Bridging institutional divides. Journal of International Management, 16(4), 398-411.

Scott, W. R., 2001. Institutions and organizations, 2nd ed., Sage Publications, Thousand Oaks.

Sepulveda, L., Syrett, S., Lyon, F., 2011. Population superdiversity and new migrant enterprise: The case of London. Entrepreneurship \& Regional Development, 23(7-8), 469-497.

Smallbone, D., Bertotti, M., Ekanem, I., 2005. Diversification in ethnic minority business: The case of Asians in London's creative industries. Journal of small business and enterprise development, 12(1), 41-56.

Smith, W. K., Tracey, P., 2016. Institutional complexity and paradox theory: Complementarities of competing demands. Strategic Organization, 14(4), 455-466

Sobel, R. S., 2008. Testing Baumol: Institutional quality and the productivity of entrepreneurship. Journal of Business Venturing, 23(6), 641-655.

Spencer, J. W., Murtha, T. P., Lenway, S. A., 2005. How governments matter to new industry creation. Academy of Management Review, 30(2), 321-337.

Stoyanov, S., Woodward, R., Stoyanova, V., 2018a. Simple word of mouth or complex resource orchestration for overcoming liabilities of outsidership. Journal of Management, 44(8), 3151-3175.

Stoyanov, S., Woodward, R., Stoyanova, V., 2018b. The embedding of transnational entrepreneurs in diaspora networks: Leveraging the assets of foreignness. Management International Review, 58:281-312

Su, J., Zhai, Q., Karlsson, T., 2017. Beyond Red Tape and Fools: Institutional Theory in Entrepreneurship Research, 1992-2014. Entrepreneurship Theory and Practice, 41(4), 505-531

Syrett, S., Sepulveda, L., 2012. Urban governance and economic development in the diverse city. European Urban and Regional Studies, 19(3), 238-253.

Teixeira, C., Lo, L., Truelove, M., 2007. Immigrant entrepreneurship, institutional discrimination, and implications for public policy: a case study in Toronto. Environment and Planning C: Government and Policy, 25(2), 176-193.

The United Nations (2017. International migration report http://www.un.org/en/development/desa/population/migration/publications/migrationrepo rt/docs/MigrationReport2017_Highlights.pdf [Accessed on 10 May 2018]

The World Bank Group (2017. Migration and development brief 27. Migration and remittances: Recent development and outlook. Special topic: Global Compact on Migration. http://pubdocs.worldbank.org/en/992371492706371662/MigrationandDevelopmentBrief 27.pdf [Accessed on 20 May 2018]

Tonoyan, V., Strohmeyer, R., Habib, M., Perlitz, M., 2010. Corruption and entrepreneurship: How formal and informal institutions shape small firm behavior in transition and mature market economies. Entrepreneurship Theory and Practice, 34(5), 803-831.

Tracey, P., Phillips, N., 2011. Entrepreneurship in emerging markets. Strategies for new venture creation in uncertain institutional contexts. Management International Review, 51(1), 2339.

Tung, R. L., 2008. Brain circulation, diaspora, and international competitiveness. European Management Journal, 26(5), 298-304.

Van Burg, E., Romme, A. G. L., 2014. Creating the future together: Toward a framework for research synthesis in entrepreneurship. Entrepreneurship Theory and Practice, 38(2), 369397.

van Burg, J. C., Podoynitsyna, K. S., Beck, L., Lommelen, T., 2011. Less becomes more: The relationship between constraints and opportunity identification in SME's. In Frontiers of Entrepreneurship Research Syracuse, NY: BCERC. 
Villares-Varela, M., Ram, M., Jones, T., 2018. Bricolage as Survival, Growth and Transformation: The Role of Patch-Working in the Social Agency of Migrant Entrepreneurs. Work, Employment and Society, 32(5), 942-962.

Walker, D. \& Myrick, F., 2006. Grounded theory: An exploration of process and procedure. Qualitative Health Research, 16(4), 547-159.

Welter, F., Smallbone, D., 2011. Institutional perspectives on entrepreneurial behavior in challenging environments. Journal of Small Business Management, 49(1), 107-125.

Wills, J., May, J., Datta, K., Evans, Y., Herbert, J., McIlwaine, C., 2009. London's Migrant Division of Labour. European Urban and Regional Studies, 16(3), 257-271.

World Migration Report. 2015. Migrants and Cities: New Partnerships to Manage Mobility, International Organization for Migration (IOM), available at https://www.iom.int/worldmigration-report-2015.

Yin, R. K., 2014. Case Study Research Design and Methods (5th ed.) Thousand Oaks, CA: Sage.

You, K., Dal Bianco, S., Lin, Z., Amankwah-Amoah, J. 2019. Bridging technology divide to improve business environment: Insights from African nations. Journal of Business Research, 97, 268-280.

Zeleza, P. T., 2005. Rewriting the African diaspora: beyond the Black Atlantic. African Affairs, 104(414), 35-68.

Zhu, Y., Wittmann, X., Peng, M. W., 2012. Institution-based barriers to innovation in SMEs in China. Asia Pacific Journal of Management, 29(4), 1131-1142.

Zoogah, D. B., Peng, M. W., Woldu, H., 2015. Institutions, resources, and organizational effectiveness in Africa. Academy of Management Perspectives, 29, 7-3 
First Order Quotes

"Registering a company is supposed to be a straightforward process but ... this process can take you more than two or three weeks (ADE 15)

"The duty and the tax system are not fair ... (ADE 13)

"I can say that the difficulty in getting access to credit is not helping the business to expand" (ADE 2).

"When our vehicle was stolen we went to the police force to report it, the police asked us is that they needed money from us (ADE 12)
Second Order Themes

Aggregate Categories of

Challenges and Motivators

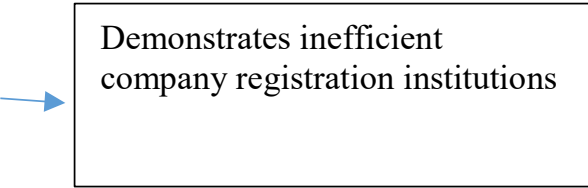

Demonstrates inefficient Customs/Excise and Tax institutions

Demonstrates inefficient financial services

$\longrightarrow$ financial services

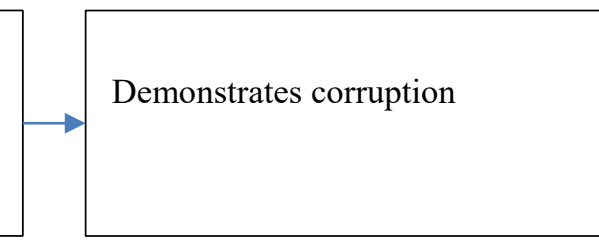

Weak Formal Institutions

--Inefficient

Customs

\&Excise duties -Corruption --Insufficient capital
"I rely on the family to progress my business, they give me advice and are doing the footwork...I trust them" (ADE 9)

"I had to rely on my parents because it's more of trust" (ADE 1)
"Most of the clients we have ... came through referrals.. and we need to maintain good relations with them" (ADE 8)

"If you are somebody who does not have that network ... it is going to cost you a lot of money to run such business in Africa." (ADE 7)
Demonstrates importance of family in diaspora enterprise
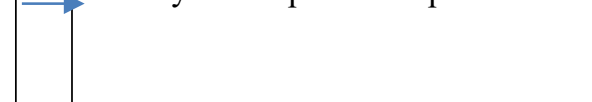

Demonstrate importance of family in diaspora enterprise development

Demonstrates importance of personal and business networks

Demonstrates importance of personal and business networks

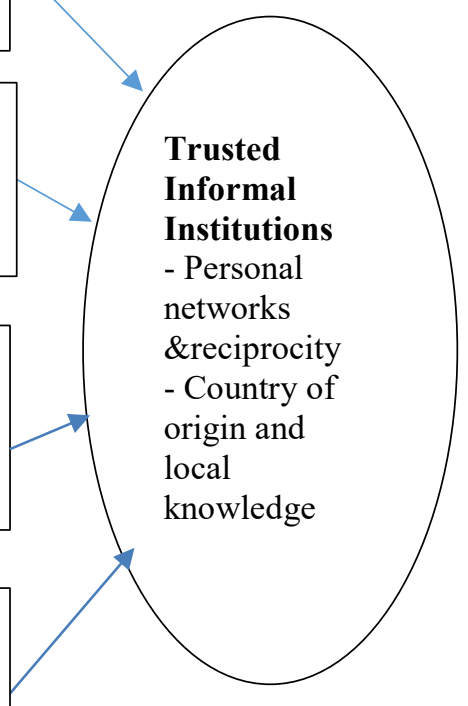




\section{Appendix 2: Example of Data Structure Country of Residence}

First- Order Quotes

"Even with the right qualification it is not easy as an African to get a job" (ADE 10)
Second Order Themes

Aggregate Categories of Challenges and Motivators

\section{"I have a business here but it is difficult to get financial support because I am black" (ADE 8) \\ (ADE 10$)$

(AD 8$)$

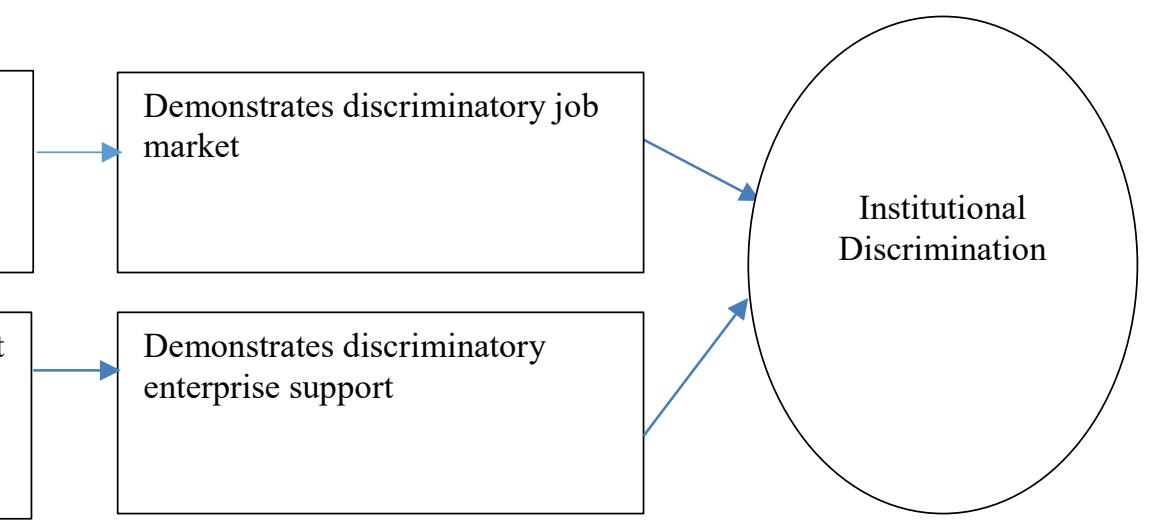

"The tax system here is fair and transparent" (ADE 4)

"Here in UK there is access to business infrastructure that helps businesses to grow" (ADE 6)

"Access to information is not a problem here and many agencies provide them" (ADE 9)

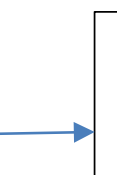

Demonstrates efficient regulatory institutions

Demonstrates availability of enterprise support institutions

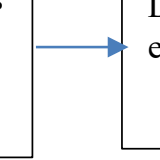

.

Demonstrate strong enterprise support institutions

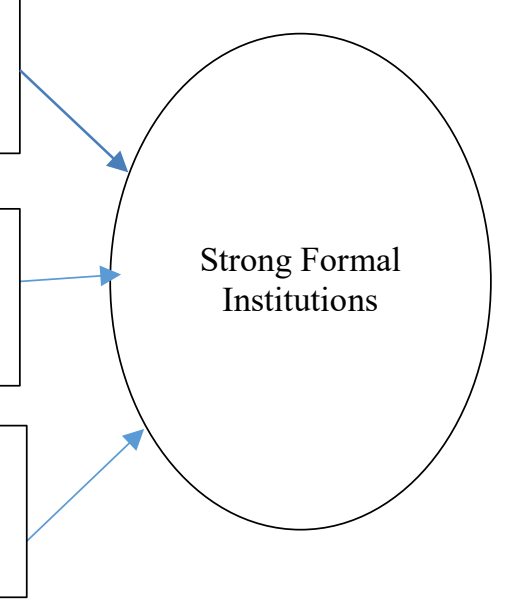

"In Ghana, sometimes, when it rains, they don't go to work ...but here, even when it is raining you have to pick your bag and go to work." (ADE 13)

"It is a different culture here and if you are offered a job and you don't deliver you are out" (ADE 4).

Demonstrates strong need for performance at work

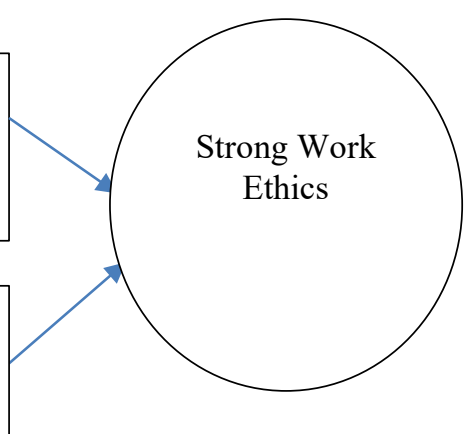


Figure 1: Diaspora Entrepreneurs' Motivation for Enterprise Development (DEMED) model

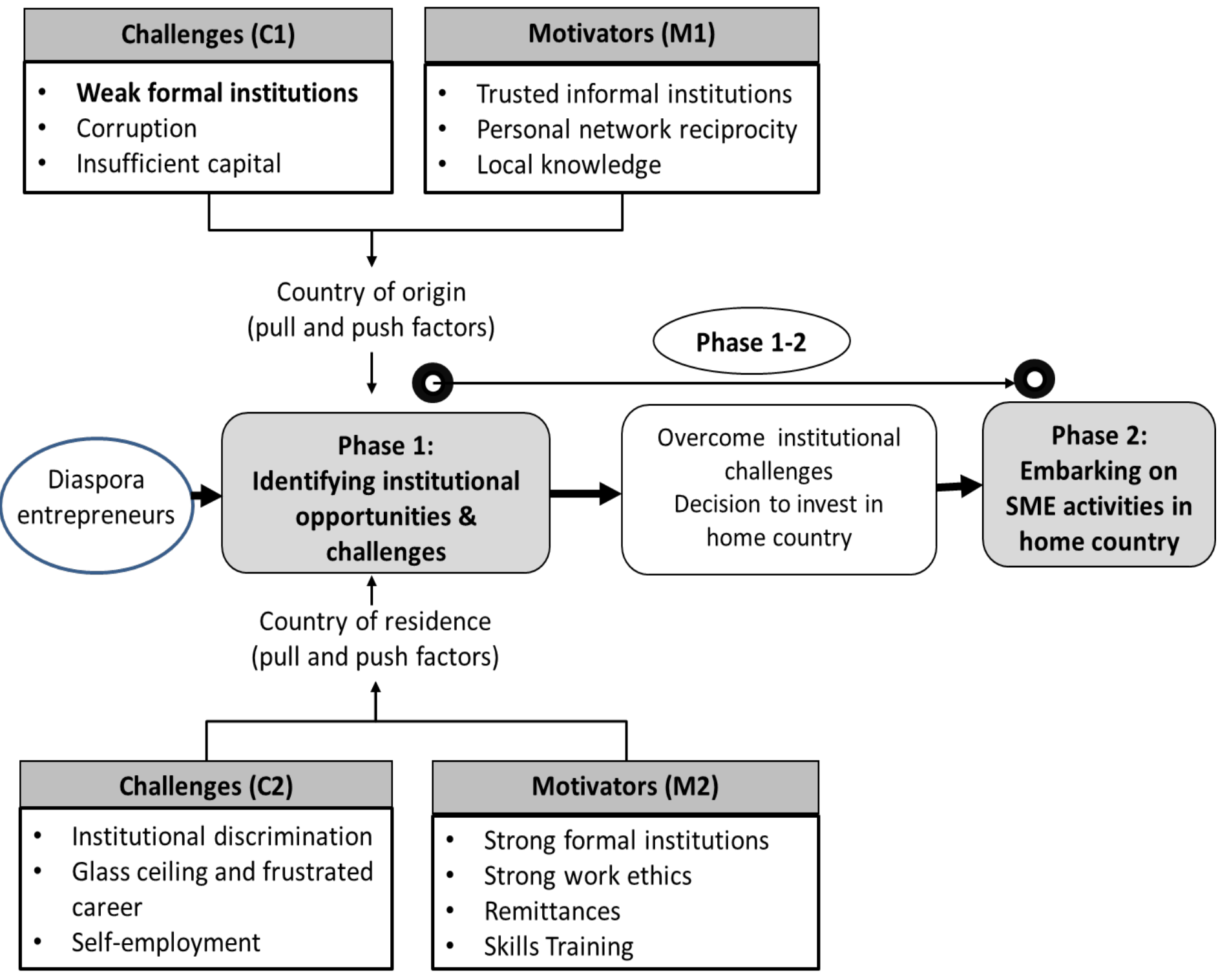


Table 1: Summary of informants' details

\begin{tabular}{|c|c|c|c|c|c|c|}
\hline Number & $\begin{array}{l}\text { African diaspora } \\
\text { entrepreneurs }\end{array}$ & $\begin{array}{l}\text { Industry or sectors of } \\
\text { their venture }\end{array}$ & $\begin{array}{l}\text { Timeframe } \\
\text { (years in the } \\
\text { diaspora) }\end{array}$ & $\begin{array}{l}\text { Academic/ } \\
\text { Professional } \\
\text { Qualifications } \\
\text { achieved in UK }\end{array}$ & $\begin{array}{l}\text { Experience prior } \\
\text { to formation of } \\
\text { the business }\end{array}$ & Motivation for entering entrepreneurship \\
\hline \multicolumn{7}{|c|}{ Social enterprise model category } \\
\hline $\begin{array}{l}\text { African diaspora } \\
\text { entrepreneurs } \\
\text { (ADE) } 1\end{array}$ & $\begin{array}{l}\text { (A) Social } \\
\text { entrepreneur } 1 \\
\text { (Ghanaian diaspora) }\end{array}$ & Clothing sales in Ghana. & 15 years & $\begin{array}{l}\text { BA in Business } \\
\text { Management }\end{array}$ & $\begin{array}{l}\text { Trustee for an } \\
\text { NGO, NHS } \\
\text { manager }\end{array}$ & $\begin{array}{l}\text { - Offer opportunities to street children in Accra, } \\
\text { Ghana } \\
\text { - Obtain support from parents in Ghana }\end{array}$ \\
\hline $\mathrm{ADE} 2$ & $\begin{array}{l}\text { (B) Social } \\
\text { entrepreneur } 2 \\
\text { (Malawian diaspora) }\end{array}$ & $\begin{array}{l}\text { Health sector trading in } \\
\text { Malawi. }\end{array}$ & 16 years & PhD in Marketing & Lecturer & $\begin{array}{l}\text { Provide better health care to pregnant women in } \\
\text { Malawi }\end{array}$ \\
\hline ADE 3 & $\begin{array}{l}\text { (C) Social } \\
\text { entrepreneur } 3- \\
\text { (Cameroonian) }\end{array}$ & $\begin{array}{l}\text { Mobile money transfer to } \\
\text { Kenya, Cameroon, } \\
\text { Nigeria, Ghana and } \\
\text { Sierra Leone. }\end{array}$ & 8 years & $\begin{array}{l}\text { MSc in Business } \\
\text { Management }\end{array}$ & $\begin{array}{l}\text { Social } \\
\text { entrepreneur }\end{array}$ & $\begin{array}{l}\text { - Uphold the belief in the African movement } \\
\text { - Offer mobile financial services to women who } \\
\text { lack access to banking services in Africa. }\end{array}$ \\
\hline ADE 4 & $\begin{array}{l}\text { (D) Social } \\
\text { Entrepreneur } 4 \\
\text { (Gambian) }\end{array}$ & $\begin{array}{l}\text { Clothing manufacturing } \\
\text { in Gambia, Nigeria and } \\
\text { Kenya }\end{array}$ & 7 years & $\begin{array}{l}\text { PhD in Social } \\
\text { Entrepreneurship }\end{array}$ & Lecturer & $\begin{array}{l}\text { - Create opportunities for artisans in the clothing } \\
\text { industry }\end{array}$ \\
\hline \multicolumn{7}{|c|}{ For-profit model category (Type 1) } \\
\hline ADE 5 & $\begin{array}{l}\text { (D) Money-transfer } \\
\text { entrepreneur } 1 \\
\text { (Ghanaian diaspora) }\end{array}$ & $\begin{array}{l}\text { Money transfer to } \\
\text { Zimbabwe and Ghana. }\end{array}$ & $\begin{array}{l}5 \text { years }(4 \\
\text { years in } \\
\text { business })\end{array}$ & $\begin{array}{l}\text { Postgraduate in } \\
\text { Financial } \\
\text { management }\end{array}$ & Financial services & $\begin{array}{l}\text { Provide fast and reliable options for receiving } \\
\text { customers to claim their remittances from abroad }\end{array}$ \\
\hline ADE 6 & $\begin{array}{l}\text { (E) Money-transfer } \\
\text { entrepreneur } 2 \text { - } \\
\text { (Zimbabwean } \\
\text { diaspora) }\end{array}$ & $\begin{array}{l}\text { Money transfer to } \\
\text { Zimbabwe and Ghana. }\end{array}$ & $\begin{array}{l}21 \text { years }(4 \\
\text { years in } \\
\text { business })\end{array}$ & $\begin{array}{l}\text { Postgraduate in } \\
\text { Management }\end{array}$ & Financial services & $\begin{array}{l}\text { Undertake practices based on family-business } \\
\text { principles with } 100 \% \text { trust and commitment, } \\
\text { both in Ghana and the UK. } \\
\text { Exploit expertise in risk calculations and make } \\
\text { allowance for currency fluctuations }\end{array}$ \\
\hline ADE 7 & $\begin{array}{l}\text { (F) Money-transfer } \\
\text { entrepreneur } 3 \text { - } \\
\text { (Zimbabwean } \\
\text { diaspora) }\end{array}$ & $\begin{array}{l}\text { Money transfer to } \\
\text { Zimbabwe and Ghana. }\end{array}$ & $\begin{array}{l}25 \text { years }(4 \\
\text { years in } \\
\text { business })\end{array}$ & $\begin{array}{l}\text { Postgraduate in } \\
\text { Financial } \\
\text { Management }\end{array}$ & Management & $\begin{array}{l}\text { Serve and support diaspora community to remit } \\
\text { money to their native countries. } \\
\text { Create easy remittance corridors for African } \\
\text { immigrants in the UK. } \\
\text { Provide self-financing funds from some projects } \\
\text { being run in Ghana and already accumulated } \\
\text { foreign reserves. }\end{array}$ \\
\hline ADE 8 & (G) Nigerian diaspora & $\begin{array}{l}\text { Accountancy and } \\
\text { consulting services in the } \\
\text { UK and Nigeria. }\end{array}$ & $\begin{array}{l}11 \text { years }(9 \\
\text { years in } \\
\text { business })\end{array}$ & $\begin{array}{l}\text { Chartered } \\
\text { Accountant } \\
\text { (FCCA/FCA) }\end{array}$ & Accountancy & $\begin{array}{l}\text { - Provide accountancy services for the community } \\
\text { and some targeted SME clientele group. } \\
\text { Encourage the establishment of self-employed } \\
\text { accountancy firm and reduce diaspora } \\
\text { unemployment in the UK }\end{array}$ \\
\hline
\end{tabular}




\begin{tabular}{|c|c|c|c|c|c|c|}
\hline & & & & & & $\begin{array}{l}\text { - Utilise the acquired skills and knowledge for } \\
\text { effective business support and management }\end{array}$ \\
\hline ADE 9 & $\begin{array}{l}\text { (H) Malawian } \\
\text { diaspora }\end{array}$ & $\begin{array}{l}\text { Financial consulting in } \\
\text { Malawi. }\end{array}$ & $\begin{array}{l}14 \text { years }(2 \\
\text { years in } \\
\text { business) }\end{array}$ & $\begin{array}{l}\text { BA Degree in } \\
\text { Management }\end{array}$ & $\begin{array}{l}\text { Public sector } \\
\text { worker }\end{array}$ & $\begin{array}{ll}\text { - } & \text { Obtain labour and credit support from family } \\
\text { - } & \text { Obtain } 100 \% \text { trust from family } \\
\text { - Help community in business development } \\
\text { initiatives } \\
\text { - Transfer knowledge and skills obtained from } \\
\text { working in the UK formal setting to Africa }\end{array}$ \\
\hline ADE 10 & (I) Nigerian diaspora & $\begin{array}{l}\text { Real estate management } \\
\text { in Nigeria. }\end{array}$ & 7 years & $\begin{array}{l}\text { MSc in Business } \\
\text { Management }\end{array}$ & Events manager & $\begin{array}{l}\text { Exploit the opportunities for making money in } \\
\text { Africa. } \\
\text { - Offer opportunities to others in Africa. }\end{array}$ \\
\hline ADE 11 & (J) Nigerian diaspora & $\begin{array}{l}\text { Oil and gas services in } \\
\text { Nigeria. }\end{array}$ & $\begin{array}{l}\text { Over } 30 \text { years } \\
\text { ( } 4 \text { years in } \\
\text { business) }\end{array}$ & $\begin{array}{l}\text { MSc in Financial } \\
\text { Management }\end{array}$ & Banker & $\begin{array}{l}\text { Aspire to be self-development in business } \\
\text { - Exploit the potential opportunities for growth in } \\
\text { Africa } \\
\text { Draw knowledge from the UK corporate } \\
\text { environment. }\end{array}$ \\
\hline \multicolumn{7}{|c|}{ For-profit model category (Type 2) } \\
\hline ADE 12 & (K) Nigerian diaspora & $\begin{array}{l}\text { Logistics and delivery } \\
\text { between the UK and } \\
\text { Nigeria. }\end{array}$ & $\begin{array}{l}8 \text { years }(5 \\
\text { years in } \\
\text { business) }\end{array}$ & $\begin{array}{l}\text { BSc in } \\
\text { Management }\end{array}$ & Self-employed & $\begin{array}{l}\text { - } \begin{array}{l}\text { Demonstrate the passion for owning independent } \\
\text { business }\end{array} \\
\text { - Obtain the family members' support through } \\
\text { word-of-mouth publicity and marketing support } \\
\text { - Apply the ideas from former business partner } \\
\text { - Raise money from previous job and added it to } \\
\text { own savings } \\
\text { - Engage in flexible franchising options }\end{array}$ \\
\hline ADE 13 & $\begin{array}{l}\text { (L) Ghanaian } \\
\text { diaspora }\end{array}$ & $\begin{array}{l}\text { Second-hand car-parts } \\
\text { dealing (1) in Ghana. }\end{array}$ & $\begin{array}{l}25 \text { years }(7 \\
\text { years in } \\
\text { business) }\end{array}$ & $\begin{array}{l}\text { Transport } \\
\text { industry-based } \\
\text { training }\end{array}$ & Truck driver & $\begin{array}{l}\text { - Seize the opportunity to make money } \\
\text { - } \quad \text { Obtain support from family members } \\
\text { - } \quad \text { eize the advantage of the improved macro } \\
\text { ents and stable currencies, prices, etc. }\end{array}$ \\
\hline ADE 14 & $\begin{array}{l}\text { (M) Cameroonian } \\
\text { diaspora }\end{array}$ & $\begin{array}{l}\text { Second-hand car-parts } \\
\text { dealing (2) in Cameroon. }\end{array}$ & $\begin{array}{l}32 \text { years }(10 \\
\text { years in } \\
\text { business })\end{array}$ & $\begin{array}{l}\text { Postgraduate } \\
\text { Certificate in } \\
\text { Education }\end{array}$ & Taxi driver & $\begin{array}{l}\text { Explore business in Africa as a last resort to } \\
\text { survive in a competitive hi-tech and } \\
\text { impenetrable glass-ceiling formal sector in the } \\
\text { UK } \\
\text { - Provide spare parts for car owners in Africa } \\
\text { - Create job opportunities for friends and family }\end{array}$ \\
\hline ADE 15 & (N) Nigerian diaspora & $\begin{array}{l}\text { Fashion design service in } \\
\text { Nigeria. }\end{array}$ & 16 years & $\begin{array}{l}\mathrm{PhD} \text { in } \\
\text { Entrepreneurship }\end{array}$ & Banker & $\begin{array}{l}\text { - Recognise the opportunity for making money in } \\
\text { Africa } \\
\text { - Obtain support from family members }\end{array}$ \\
\hline
\end{tabular}

